\title{
THE WATER POWER SITUATION, INCLUDING ITS FINANCIAL ASPECT
}

\author{
BY GANO DUNN
}

\section{Abstract of Paper}

The endeavor of this paper is to present, from the point of view of the engineer, certain aspects of the attitude of capital towards water powers. Actual and threatened laws, popular prejudices, and some cases of unprofitable developments in the past, have retarded the development of water powers, but there are also physical and natural difficulties which handicap hydroelectric as compared with steam-electric plants, and make it essential that a reasonable profit in promotion be offered, in order to induce investment.

The cost of water power is rising, on account of the increasing cost of labor and materials and increasing taxation, and the efficiency of the utilization of water power has practically reached its maximum. On the other hand, the cost of steamelectric power is falling, in spite of a steady rise in the cost of coal, because continual improvements are being made in the efficiency of conversion of heat energy into mechanical power, and still further progress is to be looked for. To offset the disadvantage of the increasing cost of water power there is the possibility of utilizing large amounts of secondary power from hydroelectric plants for industries and process purposes that do not necessarily require continuous power.

The hydroelectric plant usually requires about three times the capital investment needed for a steam-electric plant of equal capacity, and the activity of capital in a hydroelectric plant is very low, much lower than in a steam station and in almost all other branches of industry.

State regulatory bodies have hampered water powers by not recognizing the distinction between bond interest as a compulsory expense paid as the rent for money loaned, and dividends as an earned reward for the risk of the business and skill in management. Another factor that must be more clearly determined in order that the hampering effect of uncertainty may be removed, is the length of time a permit or franchise may run before recapture clauses can take effect, and the question whether these provisions should not cover the power development in its entirety.

Water power should be developed as a matter of conservation, to save our coal supply that is being so steadily depleted. This purpose cannot be served unless the attitude toward water power development is changed and some of the present restrictive factors ameliorated so that investors in water power bonds will be satisfied with five per cent interest instead of requiring seven per cent because of the risks they incur at present. 
LTHOUGH the development of water powers is almost
wholly a matter of civil and mechanical engineering, their interests have been largely in the hands of electrical engineers. Until electrical engineers created the art of transmitting power over long distances the usefulness of water powers was local and the extent of their development did not exceed one million horse power in the United States.

During the past two decades electric transmission has extended the commercial water power radius from a few miles up to say two hundred. As the art of electrical engineering has progressed and water power has consequently been transformed from a local peculiarity or advantage to an almost universal utility, an intensive development has taken place, energizing for useful purposes thousands of miles of transmission highways and almost innumerable distribution networks with power which formerly wasted itself in the erosion of stream beds and the heating of of their contents.

The profession of electrical engineering has been stimulated by the reaction of this development and has in turn come to depend considerably upon it. Electrical engineers regard the welfare of water powers as identified with the welfare of a large part of their own activities.

The relation of the American Institute of Electrical Engineers to the government of the United States in connection with water powers is an enviable one and is highly valued by the Institute's 8000 members.

In 1911 the National Waterways Commission of the $62 \mathrm{~d}$ Congress invited the American Institute of Electrical Engineers to send representatives to the hearings of the commission in Washington. In response, the governing body of the Institute created a special Committee on the Development of Water Powers, authorizing it to testify before the commission and put its expert knowledge and experience in every way at the commission's service.

The services of this committee, composed of the country's leading technical experts on water power, were appreciated by the commission and led to the extension of other invitations to the American Institute of Electrical Engineers to send similar representatives to congressional and departmental hearings in Washington in connection with water power legislation. Among these invitations was one from the Secretary of the Interior, one from the House Committee on Arid Lands, one from the 
Senate Committee on Public Lands, and more recently one from the Portland Conference of Western Governors, and others.

The governing body of the Institute has continued its special committee in consequence of these successive invitations and in view of the apparent appreciation on the part of the government that the services rendered by the American Institute of Electrical Engineers were scientific and professional and not commercial or political, that its committee dealt with fundamental engineering and economic principles of hydroelectric development that were outside the field of controversy, and that the function of the Institute being scientific and professional and not commercial or political, its status was one involving a high degree of disinterestedness in respect to matters on which its technical advice was sought.

The present meeting of the American Institute of Electrical Engineers in Washington is held under the auspices of this committee and is devoted to an engineering and economic discussion of water powers in the hope of turning all the light possible upon the subject.

As indicated by the duties honorably discharged by the Special Committee on the Development of Water Powers, the engineer's function has become considerably broader than one of pure engineering. By a group of promoters seeking capital, the engineer is usually engaged to make preliminary studies and trial designs until he selects the most advantageous site for and determines the most satisfactory miminum cost of a given development. His work, however, does not stop here, for he is called upon next to make studies of the probable market for power and to estimate expected revenue and operating expenses, including taxes and depreciation, and further since the relation of engineering and economics is so intimate, the preparation of the economic prospectus usually falls to his lot.

With such a prospectus the promoters solicit the support of one or more investment bankers, and the name and standing of the engineer is an extremely large factor in establishing the confidence of the bankers and obtaining their recommendation of the securities of the project to their clients. The criticisms and objections which the bankers cortstantly raise in reply to the proposals of the promoters have to be answered largely by the engineer, who often reforms his designs many times and has to prove exhaustively his estimates of revenue, capacity, operating expenses and other items before the bankers take up the project, 
if they do. Generally speaking and especially in recent years not more than one project in a hundred passes muster.

The engineer therefore usually develops a relation to the financing of water powers, which finds him on behalf of his employers knocking at the doors of capital and using all the abilities he can honorably employ to invite for his client's project the confidence and support of the experts of capital, and he thus acquires a knowledge of the conditions required by capital to be met before financing can be accomplished and he is enabled to take a broader view of the water power situation than one that is merely an engineering view.

The other papers presented at this meeting deal with the value of water powers to the electrochemical industries, to the food problem, to increased transportation and to national defense. In this paper I shall endeavor to present very briefly, from the point of view of the engineer as derived from experience, certain aspects of the attitude of capital towards water powers.

It has already been implied that no matter how useful a public service a water power might perform, no matter how great the need of a community for cheap power to invite industrial development, no matter how powerful the river nor high the falls, nor anxious the promoters, a water power plant will not be built unless the investment banker or his equivalent supplies the means.

The investment banker, generally speaking, is not a capitalist, but a captain for the capital of others. They follow his leadership so long as his record warrants it and they gladly accord him a commission in return for sound adviçe and guidance as to yield and security for the investment of their savings. These others are countless and are in part scattered throughout the earth. The complicated interrelations of capital among the great capital-producing nations are at once intimate and delicate so that capital may truly be likened to an international fluid, quick to flow towards its level of advantage and equally quick to cease flowing when that advantage diminishes. Prior to investment, capital is above the law. It must be consulted and courted or it cannot be won, and it usually requires of a suitor a good previous character. These are facts, no matter what may be our individual theories of government, of economics, or of social relations.

Part of the acknowledged "water power situation" is due to the scarecrow of financial losses which, contrary to 
popular information, have been suffered in water power investments. In cases where losses have not been sustained the actual yield as compared to the expected yield has been very generally disappointing. It seems conservative to assert in respect to a majority of water power investments today, that if the holders were not already in they would not go in if they were free to repeat their investment. Investment bankers of a decade or more ago sometimes piloted their clients with honest confidence into water power projects sound in the prospectus, but so disappointing in the light of later reality as to cost them their financial leadership and render their successors increasingly conservative.

There has been a considerable degree of popular prejudice and misapprehension that conceives water powers to be almost illegitimately profitable. It has had a share in making them the prey of local hold-ups for necessary real estate, flowage rights, relocation of railroads, local taxes and damage suits. But the most serious cause of the above kind that is responsible for the "situation" consists of the inhibition imposed unintentionally, or perhaps it would be better to say unwittingly, upon the investment of capital in water power enterprises, by certain laws, administrative regulations and precedents.

These laws have been both actual and threatened, and in many respects a threatened law is worse than an actual one in the check it gives to investment. Among such actual or threatened laws are those which, limiting the tenure of a grantee, provide for recapture without compensation or with only such compensation as would involve serious loss, or for the recapture of only a part of a system at a fair value for that part, but that part so essential that without it the whole system could no longer thrive.

There is a large group of legislative proposals that look upon water powers as a source of taxation or of government profits through the sharing of earnings. They lay a tax upon energy output, gross receipts, installed capacity or first cost of a development, which tax, although appearing small, amounts to a burdensome and deterrent proportion of the net profits after bond interest.

The grantee is required to construct at his own cost extensive locks and navigation works in cases where he might seem in justice rather to deserve a subsidy for his service to navigation through the erection of a dam that increases the navigability of the stream for many miles and assists in the regulation of its floods. These services, it would seem, should at least relieve him of the burden of additional cost for the locks, which is a drag upon his profits. 
Among other menaces to the security and yield of water power capital is the reposing in an administrative officer of the government of a discretion which, while presumably it would never be abused, permits the possibility of abuse by some one of a numerous succession of incumbents, and often therefore in effect causes the title to millions of dollars worth of property to rest upon normal individual discretion instead of upon definitely stated laws that permit the whole of a given future to be securely calculated upon. While clothed with great powers, such officers do not have the co-relative power to make agreements or stipulations that may be relied upon as binding the government.

There are also agitated serious objections to the combination of adjacent hydroelectric systems, on the ground that this permits monopoly and may be used to enhance the price of power and light to the consuming public.

With commissions for the regulation of public utility rates in practically all of the states of the Union, the combination of water powers can have no other effect than benefitting the public, for on most fundamental engineering grounds combination either actually reduces operating cost or does the equivalent of it by increasing output for a given capacity. It increases the insurance of continuity of operation and permits reduction of reserve capacity. It reduces the proportion of steam auxiliary power and enables advantage to be taken of excessive rainfall in one area to make up for occasional deficiency in another. The joint cost of distribution lines is diminished, regulation of pressure is improved, and the utilization of powers otherwise too small to be successfully utilized is made possible.

The objection to combination seems to be based upon analogy to combinations in other branches of industry and ignores fundamental engineering principles, especially in the presence of protecting state commissions. Successful opposition to combination could only result in increasing the burdens both of the public and of the developments.

Many others of the actual or threatened provisions are not only deterrents to investment, but are at the expense of the public. In this class fall all forms of taxes on output or development previously referred to. It is sometimes erroneously thought in proposing legislation of this sort that these taxes will be borne by the owners of the enterprises, but they are in fact passed on by them to the ultimate consumers. They are added to operating expenses and rates to the public are increased proportionately. The increased rates check the growth of manufac- 
tures and the increase of the use of light and render the community less attractive than other communities where, either through absence of tax or through natural advantages, lower rates obtain. With the increasing use of power in manufactures, the attraction of manufacturers to a locality is vitally affected by the rates for power that can be offered. Federal laws proposed for the taxation of water powers have naturally applied only to water powers under jurisdiction of the federal government. They inequitably leave untaxed and free from such discrimination competing private water powers and we ter powers under state jurisdiction.

It seems difficult on the part of many to accept the conclusion that by the control of rate commissions water powers are forever prevented from becoming bonanzas to their investors. Other kinds of public utility corporations are seen to be duly regulated, but there lurks a suspicion that water powers may form exceptions. While the consequences of this doubt contribute to a complacent retardation of development, the benefits of water power development to communities of large population do not seem to be adequately appreciated.

In some of the governments of Europe so greatly are the benefits of development esteemed that water powers are encouraged.

In addition to the laws, prejudices and past financial history that have retarded water powers, there are physical and natural difficulties of a very real sort which render a reasonable profit in promotion requisite to induce investment.

Power developed by a hydroelectric system must be based upon the minimum or nearly the minimum flow of the stream, unless great cost for storage is warranted. The dam, however, must be strong enough to withstand the stream in flood, often 50 to 500 times the minimum flow. A water power is liable to suffer not only from lack of water in dry season, but it is often partly drowned out at times of flood when high tail water reduces the hydraulic head. For these and other reasons most water powers require auxiliary steam power for reserve.

A large part of a hydroelectric power development consists of transmission lines exposed to lightning, wind and sleet. A water power, unlike a steam power, cannot be begun in a modest way and allowed to grow as its market gathers. The real estate, dam, rights of way, transmission towers and many other portions of the development must initially be of ultimate capacity and cost, hence during the early years there is usually a period of waiting for the growth of market when expenses 
often exceed income and owners must not only go without their profits but must often put up funds to tide the project over.

For taking the construction and operation risks and the risk of delayed development of income, to say nothing of the risks of title, taxes and adverse legislation, it can readily be seen that the profit required to tempt investment into hydroelectric projects must be at least as great, if not greater, than that offered by other utilities or industrials.

So far there have been dealt with only the checks to hydroelectric investment arising from actual or threatened legislation popular prejudice and construction risk, but, especially east of the Mississippi River where three-quarters of the mechanical power in the United States is consumed and where there are still undeveloped large resources of water power, there is an additional check that daily speaks with a louder and louder voice ruling out the water powers-even if financing were obtainable-in favor of steam produced from coal.

Increasingly large numbers of water powers that a few years ago would have been considered worthy of development by conservative financial authorities, assuming all legislative and administrative hindrances removed, are now ranged in the unworthy class because they do not meet the supreme test to which every water power project is put in the engineer's office before it can get even to the preliminary prospectus stage. This test is a comparison of the cost of the power produced by water with its cost produced in the same market by steam if some competitor should build a steam plant there.

The cost of water power in general is rising on account of the increasing cost of labor due to shorter hours in the form of three instead of two shifts and higher wages, the increasing cost of materials, and the generally increasing taxation, employers' liability and similar items of expense that are characteristic of industrial operations in the United States. In spite of all these circumstances and in spite of a steady rise in the cost of coal, the cost of steam power is steadily falling.

At equal cost the scales of the consumer's choice almost invariably turn against a water power and decide in favor of steam power biecause, among other reasons, it is generated in the market where it is consumed, whereas water power has to be brought from a distance and suffers the risks of a long transmission line. Also steam power is more flexible and is free from the influence of dry seasons or floods. Water power must be considerably the cheaper before it.can compete. 
The increasing introduction of steam power, devouring our coal fields at a time when millions of horse power of water power are undeveloped, is a crime against the policy of conservation. Each new steam plant is an agency devoted in effect to the perpetual consumption of coal, and coal is a limited commodity. While absolutely essential for smelting and practically essential for the heating of our houses, it is not essential for the production of power.

Steam power is consumed only when it is used; water power whether it is used or not. If the power of a water fall is not brought to the neighboring city to turn its wheels, do its cooking, or light its lights, the power is developed just the same at the falls and expresses itself in grinding the rocks at the bottom and the heating of the agitated water. Postponement of coal consumption would be real conservation. Postponement of water power development is real waste.

If water power, instead of being at a disadvantage compared to steam power, were fully its equal as to cost of power delivered and certainty of operation, it wculd still be at a serious disadvantage when construction is under consideration for an added reason which aggravates the whole relation of water power to capital. This is the excessive capital required for a water power as compared to that required for a steam power of the same capacity.

A typical modern steam electric station, including real estate and every other item of cost up to the distribution system, can be built for $\$ 45$ per switchboard horse power of output. A correspondingly typical hydroelectric development of the same capacity, for moderate head, including transmission lines and substation, would cost in the neighborhood of $\$ 135$ per switchboard horse power of output, which figures are in the ratio of 1 to 3 .

Capital for a steam-electric station is relatively easy to raise. The natural hazards are considerably less. The property is concentrated under one roof, instead of being distributed over many miles of country. There are no actual or threatened adverse laws to introduce doubt as to the security of investment. Popular prejudices are more likely to favor rather than to be against the economics of a steam station. Large supplies of coal are seen going into it and the public appreciates these must be paid for. The plant, to the popular eye, seems to be hot and busy and entitled to its rewards. In the case of the water power, for reasons that have been mentioned, capital is more 
difficult to raise, and besides being more difficult to raise, three times the amount is required. It is not difficult to see why, at equal cost of power delivered if it is a question of building a steam or a water power, the steam power gets the preference, and when, as is increasingly the case east of the Mississippi, the cost of a horse power-hour developed by steam is so much less than when developed by water, the "water power situation" is removed from the court of discussion before a decision is reached, because of the fatal competition of steam.

It may be asked-will the cost of steam power continue to decline, notwithstanding the continued rise in the cost of coal? There seems every reason to expect that it will, for with the best plants of today, improved as they are, the return from a pound of coal is only 17 per cent of the power it contains. Internal combustion engines operated by liquid fuel have not yet cut much figure as large sources of prime mover power, but they are constantly undergoing improvement. In the generation of steam, where boiler pressures of $150 \mathrm{lb}$. were used a few years ago $275 \mathrm{lb}$. is now used, and higher pressures up to $400 \mathrm{lb}$. are under experiment, together with higher degrees of superheat than the past has thought possible, and it is not too much to expect considerable improvement in steam economies from progress already in sight. There is also much latent possibility in the gas turbine. In view of all this, he would be rash who notwithstanding the steady moderate increase in the cost of coal would predict an increase in the cost of steam power.

While the cost of steam pcwer has fallen and is falling, due largely to an increasing efficiency in the conversion of heat into power, and while this efficiency is still so low as to render further increases not only possible but probable, the efficiency of water powers has practically reached its maximum and further reduction in the cost of water power from improvement in efficiency is barred. Reference will later be made to the only direction in which substantial reduction is possible.

The unfortunate necessity of relatively excessive capital throws difficulties into the path of water power in more ways than one. Not only is excessive capital required before the development can be created, but after it is created there is a handicap in the magnitude of the bond interest constituting the principal element of cost of operation-using this term in its broadest sense. Both by the large investment of capital required and the large return to capital appearing in its cost of operation, water power development is led conspicuously into the realm of the relations of wealth 
and capital to industry and the social system, which relations are subjects of keen political and economic controversy. The water power problem, being exceptionally dependent upon capital, is the innocent bystander that suffers from the quarrel between two struggling antagonists, both of whom its development would enormously benefit. A unit analysis of the gross operating expensesusing the term as before, in its broader sense-of the typical steam-electric and hydroelectric system I have referred to may be of interest, and is given below for annual load factors in both cases of 50 per cent and coal at $\$ 3.25$ per ton, delivered.

Unit Analysis of Gross Operating Expenses in Typical Steam-Electric and Hydro-

Electric Station of the Same Capacity, 20,000 H.P., Annual load Factor 50 Per Cent. and Producing Power at the Same Cost. Coal $\$ 3.25$ Per TON Delivered. Returns to Capital $7 \%$

\begin{tabular}{|c|c|c|}
\hline & \begin{tabular}{|} 
Steam station \\
per cent of total gross \\
operating expenses
\end{tabular} & $\begin{array}{c}\text { Hydroelectric station } \\
\text { per cent of total gross } \\
\text { operating expenses }\end{array}$ \\
\hline 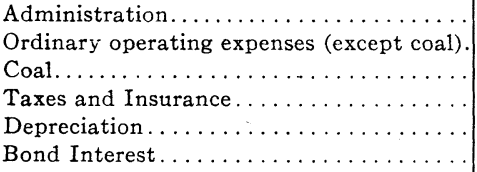 & $\begin{array}{r}4.0 \\
10.6 \\
48.9 \\
6.7 \\
10.8 \\
19.0\end{array}$ & $\begin{array}{r}4.0 \\
4.8 \\
\cdots \\
2.8 \\
11.0 \\
77.4\end{array}$ \\
\hline Total... & 100. & 100. \\
\hline
\end{tabular}

As will be seen from the table, bond interest is the largest hydroelectric expense. In the typical case considered it constitutes 77.4 per cent of the total operating expenses. In the steam station it is only 19 per cent.

The largest expense in the steam station is coal, amounting to 49 per cent of the total. This everyone can understand and nobody begrudges; but there is a small body of opinion which considers all interest usury and to this group the fact that over threefourths of the cost of producing power in a water power plant represents interest is almost equivalent to saying that the cost of water power ought to be reduced by three-quarters. The whole cost for coal in the steam station is only two-thirds of the cost for interest in the water power.

The classification of bond interest in each case under the head of operating expenses is not customary, but is done for the purpose of giving a clear conception of the radical difference between the compulsory items of expense in the two types of stations.

There is a tendency in many quarters to regard bond interest as profits. This is fundamentally erroneous. It is comparable to regarding the rent a grocer pays for his store as profits. His profits do not begin until after the rent is paid under penalty of 
eviction, and similarly the profits of a water power do not begin until after the bond interest, which is rent for the borrowed money, has been paid under similar penalty of eviction by the foreclosure of the mortgage. The holders of the bonds have no interest in the profits of the development. Their returns are set by the prevailing rate of interest in the bond market, and not by the prosperity of the enterprise. They get their returns, in theory at least, whether there are profits or not. It is true that bond interest is sometimes in default, but the holders have the right to take possession of the pledged property, foreclosing and recouping themselves out of the proceeds of its sale for both principal and defaulted interest. It is partly by regarding bond interest as profit that the impression that water powers are very profitable has gained acceptance.

It is natural for a spectator surveying a hydroelectric development to gain the impression that the power comes from the water, which, costing nothing, should render the power cheap. It is evident to a spectator that outside of bond interest the operating expenses of a water power are relatively very low, being in our typical case only 22.5 per cent of the total, which includes ample allowance for depreciation, taxes and insurance. But so much of a dam is in hidden foundations and in parts under water and so much of the long transmission line, rights-of-way and power house and substations is out of view to a spectator, that even though he be liberally inclined towards the deserts of capital, he constantly underestimates the amount of capital invested and neglects to include in his conception of the cost of the power, adequate charges for the service of this capital.

Business men know that profits depend not only upon excess of price over cost of product, but on "turn-over-", which is the ratio of aggregate sales to capital.

If we compare a steam-electric with a hydroelectric power of the same capacity in both of which the selling price of a horse power-hour is the same, we must permit out of this selling price a greater proportion of gross profit in the hydroelectric or we cannot yield the same return to capital, since there is three times the capital to be served. In other words, there is only one-third of the "turn-over". The activity of capital in a hydroelectric plant is very low, much lower than in a steam station, and much lower than in almost all other branches of industry such as manufacturing.

Certain public service commissions have hampered water powers by not recognizing the distinction between bond interest 
as a compulsory expense paid as the rent for money loaned, and dividends as an earned reward for the risk of the business and skill in management. They have in effect ruled that the total return for bond interest and dividends together must be limited to a certain amount-eight per cent in the recent decisions in California. The result of this in attempting to secure new capital at a time when bond interest rates are tending to rise is going to be the same as if a grocer, when his rent is raised because of improvement in the opportunities of the neighborhood, should be ordered to accept smaller profits in order to keep the total of his rent and profits the same as before. If he were free, he would decline to do business under such conditions, and if not free his plight would be a warning to others.

There has been considerable discussion about the length of term for a permit or franchise after which recapture clauses can take effect, and those interested in water power are not agreed seemingly because of difference in approach to the problem rather than difference in conviction as to the effect of certain provisions.

For a simple water power unrelated to others and not expected to grow, a fifty-year term might at first sight seem long enough to remove from influencing the raising of capital, discussions concerning the favorable or unfavorable developments final to the term. Those who are less concerned over final conditions are often, although sometimes unconsciously, relying upon the extreme improbability of the exercise of the right of recapture, with such loss as it might involve.

But ten years of the fifty would often run between the granting of a permit and the time a bond issue was put out and construction commenced, and three years more would often run before operation began, so that the recapture conditions might indeed come within the life of a forty-year bond and have a sentimental, if no other, effect upon its acceptability and price.

But growth is a characteristic of successfully located and successfully managed water powers, and ten years after the completion of construction perhaps the development of a second location further up stream by the same company becomes desirable. While a fifty-year permit for the new development may have no disadvantages, the new bonds of the company must take into view the approaching expiration of the permit on the first development, which now is only 27 years off, and by the time a threeyear period of construction of the second development is completed, will be only 24 years off. 
We now reach a time when it becomes of the highest importance to know just what the conditions and effect of recapture will be. If we are successfully to solicit capital for our new venture and if we are to continue to be able to invite industries to locate and develop in our territory, building extensive factories and communities in the security of long-term power contracts, the possible recapture of the original development must contemplate taking over not only the dam site, which is all certain proposed laws have included, but the transmission lines, substations, steam auxiliaries and all appurtenances and adjuncts that make the development an operating whole. The existing power contracts and all other contractual obligations of the development should also be part of the obligation of recapture.

In default of this the application for new capital will be unsuccessful, because there will be feared a limitation of opportunity and a disorganization of the management, possible liability for unfulfilled contracts and possible loss from recapture at a depreciated physical, instead of a fair, value.

If recapture is to be on terms involving a known definite lossin several bills reversion of dam and power house without compensation has been proposed-an appropriate sinking fund must be set up to offset this. Suppose such a sinking fund to be one per cent of the cost of the original development and to be set up thirty years in advance of the expiration of the permit. This 1 per cent expense seems small; but if we consider that the total return on the cash cost is not likely to average over 10 per cent, of which, for purpose of illustration, 7 per cent may be regarded as bond interest and 3 per cent as profits, the 1 per cent sinking fund for the amortization of the loss of recapture would absorb one-third of the profits of those owning-the equity in the venture and bearing the risks and earning the rewards of management.

Reference has been made in only a general way to term of permit and conditions of recapture in illustration of the kind of problems these questions throw into the path of promoters and engineers seeking to make water powers attractive to capital.

A number of their chief impediments are removed and water powers take on a new aspect when viewed as a source of secondary power in addition to their primary power. Capital for a given output greatly diminishes, market is rendered more stable, transmission lines are cheapened, since industries that use secondary power can locate near the development, and the cost of such secondary power manifests itself so low as to help to restore the effective competition of water with steam. In many cases secondary water power would be so much cheaper than 
steam that impetus would be given to the creation of industries and industrial processes now dormant because the cheapest steam power is too expensive. For process purposes, continuous or primary power is not necessarily required, and advantage can be taken in large numbers of cases of the enormous amounts of water power in excess of minimum flow or of partly equalized flow now wasted in other than the dry seasons. If by wise provision we can nourish our struggling water powers with the increased revenue which, generally speaking and without interfering with primary power, secondary power could yield, the total cost of both services would be so greatly reduced that water powers would again in a large number of cases assume the place they held before steam power became so cheap, and, east of the Mississippi, began to rob them of their birth-right. The water powers would then be able to conserve coal, up-build communities by cheap power, and encourage location in this country of industries that now go elsewhere.

If, in addition, the attitude of the public, and in harmony with it the attitude of the public service commissions and of the government should change toward water powers so as to regard them as friends, capital would again flow liberally and the public, the government, the capitalists, the promoters and the engineers would all be highly benefited and rewarded.

But even independently of the cultivation of secondary power a great deal can be done to develop our water powers as they are, especially west of the Mississippi where three-quarters of the water power resources lie, and where, generally speaking, on account of the high cost of coal, water power is normally cheaper than steam power. While for the time being the Pacific states and some of the mountain states seem to be over-developed in respect to water powers,--lacking market, rather than developmentthere are numerous specific cases where development is urgently needed but deterred by the considerations that have been mentioned. Power consumption per capita in the United States is increasing so rapidly that unless we wish to shut our eyes to the staggering rate at which we are making inroads upon our exhaustible coal supplies, the development of our water powers is imperative.

The West needs them to get power more cheaply than is afforded by the relatively high-priced coal and oil, and with this cheaper power it can in time work wonders in industrial and agricultural development. The East needs them as a source of power cheaper still than the already cheap steam power and as a substitute for the fuel-produced power that is eating out the vitals of our fuel 
resources, which should be conserved for purposes that only fuel can serve.

The "water power situation" is costing the country many millions annually in actual loss and in retardation of industrial development.

It has been shown that reduction in the cost of water power cannot be expected from further inventions or improvements in the art of engineering, but nevertheless the cost of water power is susceptible of considerable reduction from improvements in another direction.

In our typical case 77.4 per cent of the cost of production of a horse power-hour was composed of bond interest. The table was compiled on the assumption that money was worth seven per cent for water power purposes. If its owners could be induced to lend it for five per cent the bond interest would be reduced by 28 per cent and the cost of production of a horse power-hour by 22 per cent-a reduction important enough in many cases to turn the scales against steam power and result in the bringing of a new water power into existence.

Or if the case occured in the West, a 22 per cent reduction in power cost would go a long way towards encouraging the use of power for purposes previously out of its range.

A five per cent bond interest for the typical case is not visionary. Railroads enjoy it and many industrials.

Water powers could enjoy it if there were a change of policy towards them on the part of the public, the commissions and the government that would make investments in them secure, remove all but the property taxes they now bear, eliminate the many extra construction costs, expenses, delays, technicalities and injurious limitations they suffer, and bring them to a position of being, under the fostering care of the government, a boon to the public.

The writer, for one, thinks this change will slowly come. It has already started. Little by little the interests of the parties to the controversies are being discovered to be identical. Little by little publicity and the pure light of intelligence will permit economic laws to have their free play and the "water power situation" will disappear, giving place to a rapid development that will benefit our citizens as consumers, strengthen old and develop new industries and save our coal, putting us in a superior position not only with respect to power but in respect to the influence power is having upon the development of all the resources of the country. 
Discussion on "Water Power and Defense" (Whitney), "The Water Power Situation, Including Its Financial Aspect" (Dunn), Washington, D. C., April 26, 1916.

F. A. Lidbury: I am glad this question has been brought up, because there has been for years a tendency on the part of electrical engineers in connection with their valley load problems to assume that the electrochemical industries can offer an easy solution. The tendency appears in various ways. There is the steam central station man who comes to electrochemical manufacturers and says, "We can offer you lots of power at cheap rates if you will only take it for a few hours of the day." When you find out what he means by cheap rates you get a shock; but putting that aside, and putting aside the fact that few electrochemical processes can operate satisfactorily in an intermittent manner, let us see what he is trying to do. He is trying to relieve his prospective customer of the investment portion of the cost of the steam power. What is forgotten is that he is asking the customer to increase his own investment charges.

Putting all other considerations aside, let us see how that works out. The consensus of opinion as shown by the figures given today is that the cost of steam plants may be taken as something like $\$ 60$ per $\mathrm{kw}$. capacity. I venture to say-and I have consulted some of my electrochemical friends present who confirm the statement-that there is not an electrochemical plant in the country that does not involve an investment of at least $\$ 50$ per $\mathrm{kw}$. in plant cost. Many electrochemical plants run to several times that figure, and the average would be much higher, and might be two or three times as high. What the central station man is asking is therefore that his customer should increase his investment charges to an extent usually considerably greater than those of which he is being relieved. Intermittent operation is in some cases not possible, in others at least inconvenient; but the fundamental reason why these industries do not gobble up the off-peak of steam central stations is the one just given.

Then there is the question why electrochemical industries do not flock around those water powers which have valley power or secondary power at-in this case actually-relatively cheap rates. The answer is again that the added investment cost, taken in conjunction with disadvantages of intermittent operation, is such as to more than neutralize the advantage of the lower power rate. Partial time operation of electrochemical plants does not therefore offer much hope as a solution of these problems. I am not saying that there are not times when it can be done, but I am speaking now of normal conditions.

From the electrochemical point of view the figures given in Mr. Dunn's paper would require modification. His comparisons between the cost of power from steam and hydroelectric instal- 
lations, on the basis of a 50 per cent load factor, would be very different on the basis of a 100 per cent load factor. It is obvious from a consideration of the figures Mr. Stillwell gave this afternoon that water power costs become relatively more favorable than steam power costs as the load factor increases, and vice versa; and, as Mr. Stott pointed out this afternoon, there is under every set of conditions a point where the two curves cross. The load factor of electrochemical plants usually lies well above that point.

There is one corollary which is not usually drawn as clearly as it should be. Mr. Dunn mentioned some of the favorite legislative prescriptions put into bills in connection with water power. One of the most ridiculous of these, which occurs in almost every bill relating to water power, is a provision that preference in the distribution of such power shall be given to municipal and similar purposes. In other words, you must provide the type of power which is most costly to develop with those particular loads which have the worst load factor. It has been sufficiently pointed out today that for that kind of load, even under the most favorable water power conditions, a steam plant will do the work cheaper and better, and it is about time that we got it out of the heads of legislators that the proper, decent and reasonable thing to do is to tie a water power plant preferably to those loads of the worst possible load factor.

In connection with legislation one or two other points must be considered. There is the question of taxation of water power to which Mr. Dunn referred. It has been clearly pointed out, principally in Dr. Whitney's paper, that for certain electrochemical processes, particularly for the fixation of nitrogen, we have got to have power at much cheaper rates than at present in order to permit their development. Specific taxation of water power is not likely to lead in this direction; it simply makes it more difficult to introduce industries which the country vitally needs.

Next, as regards the provision that water power plants shall revert to the government, say at the end of 50 years. What about the consumptive industries that have sprung up around such water powers? In most cases where artificial restraints are not put upon distribution, these will largely be electrochemical plants. These plants will be useless except in connection with the water power plants, and they will be providing supplies of fundamental importance to the general industries of the country. The investment involved in these electrochemical plants will be at least as great as, probably considerably greater than the investment involved in the water power plant itself. That is a matter which should receive very careful consideration -what is going to happen to these plants, to the investment they represent, and to the industries which have become dependent on their products, if by some carelessly drawn reversion clause they are liable to be thrown on the scrap heap at the end of 50 years? 
Most of these points are more or less related to the strictly electrochemical side of the question; but I feel very strongly that either the future of most of the water powers in this country will be bound up with electrochemical industries, or there will be no future at all for them.

Lawrence Addicks: What Mr. Dunn says about seasonal variation puts a little different color on this question of off-peak power. I have been thinking of diurnal variation, and I think Mr. Lidbury was in what he said, as I certainly was in connection with what I said this afternoon. If you put to us the proposition what we shall do in the ten months of the year, our first question is-what do you mean by cheap power? Do you mean $\$ 10$ per h.p. year or anywhere near that figure?

Gano Dunn: That or better.

Lawrence Addicks: What will we do with large quantities of power at $\$ 10$ per h.p. per year, ten months a year, and nothing for the rest of the time? That requires a business which could be carried on by using the current for a part of the time, and working up the product in other ways the rest of the time, and in the few minutes I have had to consider the matter, I can not think of any case where it looks inviting. In order to comply with the proposition it means that we must use so much power in the business that the cost of the power is the main thing, and we will do anything to get cheap power and shut down the business for two months in the year, during that time paying fixed expenses and salaries.

One of the industries in which such a proposition might be considered is the nitrogen industry by the arc process, and I think it would be a very interesting thing to consider. We are now trying to get the government to consider this manufacture of nitric acid from the air, and we are talking of subsidizing the industry, and if Mr. Dunn will come forward with a proposition which will yield very cheap power ten months in the year, it would be worth considering. The arc process uses about $25,000 \mathrm{kw}$. per ton of 100 per cent nitric acid. The aluminum industry is another which might be considered in this connection.

John H. Finney: The answer to Mr. Addick's question in connection with the aluminum business is perhaps best found in the fact that we are building today something over 150,000 h.p. in hydroelectric power for the manufacture of aluminum, to work twenty-four hours a day, and 365 days in a year. I do not believe secondary power, even for ten months, would interest an organization such as ours.

I should like to comment briefly on Mr. Dunn's paper. The electrical engineer is essentially an optimist. That may not be apparent from the papers read today, and from some of the discussions, but if he were not an optimist, I do not think he would be found here today talking water power. If he were not an optimist, he would be, by this time, thoroughly discouraged by the stagnation that has existed for the last eight or ten years in 
the water power business. If he were not an optimist he would not still be trying to "unlock" as President Wilson puts it, this great natural resource and this tremendous, though latent, asset towards industrial advancement and preparedness.

The purpose of the meeting of the American Institute of Electrical Engineers and of its Water Power Committee here today was to call attention to a phase of hydroelectric development that seemingly has not had much thought by legislators and department officials who deal with this question.

We thought it might be helpful to stress the important uses to which water power can be put by the electrochemical and similar industries. Congress has in mind the value of water power measured by its public utility use solely, and the vast majority of the water powers of the United States are not in that class and never will be, in my opinion.

The great bulk of the water power in the United States is only available for what might be termed a semi-public usea so-called private use, it might be, of the electrochemical industries, the semi-public use of power for pumping water on to arid lands; serving as motive power in the electrification of steam railroads; in making fertilizers, or in making nitrates for explosives. These are not, strictly speaking, public utility uses, but are much broader, much more important, in that the energy creates not incandescent lighting for instance, but, the vastly more valuable products embraced in increased transportation, or increased agricultural production or new and cheapened products of the electric furnace or electric bath.

The public utility use of water power is mainly that of using it as a part of the combined water and steam generating system and therefore it might be no particular hardship to the public service company to have a given water power taken away from it at the end of a fifty year period, because they could at that time substitute a steam plant, or perhaps another water power plant if it were in reaching distance of their operations, but the great mass of these chemical operations, this irrigation work, this electrification of steam railways, requires, first, cheap power and secondly and just as importantly, it requires permanent power. These operations require power in perpetuity, and that is another thing that our Congressional friends do not seem to have in mind, viz. the difference between permanent use, and permanent rights. Great works of the expensive and permanent character required for the development of water power cannot be financed with the expectation or suggestion that they must be abandoned at the end of a fifty year period, or that money invested in them is subject to suspicion and to grave risk of confiscation in whole or in part.

Permanent works are built to supply a permanent use which so far as we can now see will always be performed in the same way-whether the original lessee continues to perform it or another lessee or the Government finally performs it, does 
not greatly matter, it seems to me, so long as it is proposed to deal fairly and equitably with the original lessee. Cheap water power in the United States is only possible with cheap money to build water power plants-every unnecessary property restriction causes dear money and more costly power, and materially limits the available water power resources of the nation, as has been well pointed out by Mr. Dunn and others.

If the Institute can bring about a better understanding of what these industries mean in their importance to the nation, we have felt that we would be doing ourselves credit as leaders in the electrical arts, and we would be doing the nation a service, by pointing out what we consider fundamental engineering principles and fundamental economic principles, without the recognition of which no permanent water power policy can be written by the Congress that will bring about that wide development so necessary to the industrial growth of the nation.

L. H. Baekeland: Mr. Gano Dunn referred to some statements I made this afternoon on the subject of wasteful banking. I would like to explain what I meant. Before doing so, I want to answer the remark Mr. Finney just made. He asked: "What is the real importance of some of these electrochemical industries? I could take, for instance, the manufacture of nitrogen-fertilizer which requires such very cheap power, and for which the market is almost unlimited if it can be supplied at a sufficiently low cost. In all our discussions we have been rather indefinite as to what we mean by cheap power. For instance, in the city of Yonkers, I am charged 12 cents a kilowatt hour for current. I think that is cheap, because I cannot do any better, and furthermore, the matter of annual expense in this case amounts to little. So I do not mind much the 12 cents a kilowatt hour they are charging me. I am kicking more about the ugly poles with which they are butchering the landscape and defacing my property, and I would gladly pay 15 cents per kilowatt hour and call it cheap if the company did not put its horrible poles in such inappropriate places.

But when we speak of cheap power for fertilizers we mean $\$ 4$ or $\$ 5$ per horse power-year, twenty-four hours a day continuous service. Why do we want cheap fertilizers in the United States? I was born in a country where farm labor is unusually inexpensive, and I know, therefore, that there is hardly any comparison possible between cost of farm labor in Flanders and that in the United States. In Flanders, farm labor is mostly a family affair. The peasant, his wife and children work in the fields, and they feel happy in doing so. They receive no wages; they work practically for their board, and even that does not amount to much.

When farmers, at such low rates of labor, find it profitable to utilize cheap nitrogen fertilizers-and after all fertilizer is a labor-saving device-when we see again that in this country, where farm labor is incomparably more expensive, we cannot 
afford to use cheap nitrogen fertilizer, because it costs twice as much as in Belgium or Germany, then "there is something rotten in the State of Denmark."

We can produce very cheap nitrogen fertilizer by fixing the nitrogen from the air if we have cheap power. The chemical processes to do this are well known and the sources of cheap power are here too. But for several reasons, by the time we develop the power, it has become too expensive for profitable use with these processes. Some of these reasons have been well put forth by Mr. Gano Dunn, and what I am telling you now is not in opposition to his statements. Right here is where our wasteful banking comes into play.

When twenty-seven years ago, I landed in this country, one of the first things which struck me was that most commodities here are cheap enough at their source of production, but they are tremendously more expensive by the time they reach the consumer. If I were to put it in another way, I would say that one of the curses of this country is the unnecessary multiplication of middlemen, and this situation goes against the grain of engineers or chemists who work for efficiency. Sometimes I think we are a lot of fools when we work and put forth our best skill, our best efforts, striving to increase efficiency in power production or in chemical processes so as to decrease the cost one cent, or a fraction of a cent, or to reduce power consumption a few per cent and then, after we are all through with our improvements, our increased efficiency looks like a mere trifle if we compare it with the big gap of waste which has to be bridged between the producer and the consumer.

Now in regard to water powers: Take, for instance, a suitable water-power site, including real estate and water rights. An engineer comes along and sees the possibilities of the situation for water power development. Almost immediately he is confronted with some real estate speculation in which some men have to get rich. The next step is the advent of the promoter who wants to get rich too, and most of the time very quickly. Then comes the banker and the bond-broker, and then finally the water power enterprise gets to the point where the equipment gets into the hands of a manager, and the power is now available to the consumer, who finally finds that it is too expensive for him to use it, because at each step in its development, the fixed charges have been increasing. That will not do for cheap power. Cheap powers in Norway, or other places abroad, are not burdened by those extraordinary fixed charges which were incurred by having to go through all these middlemen. Whenever one set of financiers or underwriters control the whole enterprise from the inception of the water power to the construction of the chemical works and the delivery of the final manufactured product to the consumer, it stands to reason that the final cost of the water power will be cheaper. In some cases here in the United States, I found that the cost of operating water power 
represents only 10 per cent of the fixed charges introduced by banking or financing, so that any important reduction of the cost has to be found more in the financial end than in the engineering or operating part of the proposition.

Now, what would you say, for instance, if you started to manufacture sulphuric acid, and if first of all your plant is located on a piece of leased ground where you are compelled to pay such an exorbitant rent because the people who possess the real estate have to get rich by it, and then when you purchase your raw materials, another set of people have to levy considerable profit on this, while you, as a manufacturer, would have to get your share in the manufacturing operations after being confronted then again with a selling agency which would claim high commissions, until finally the product, after getting through the hands of all those middlemen, comes in the hands of the consumer at a greatly increased cost. The up-to-date sulphuric acid manufacturer, in order to make a success of his enterprise, begins by owning land or real estate, and he secures his raw materials directly, and when it comes to selling, he does not have to go through the additional expense of middlemen. Therefore, he can afford to deliver his sulphuric acid at a minimum cost. Somehow, we have not yet reached that point in the utilization of our water powers. It is true that in some cases, none of the intermediaries get very much separately, but in the end, they all get something, and these expenses are multiplied collectively until they sum up to a considerable increase in the cost of power, and that is the reason why our water powers are generally so much more expensive than they are in some other countries.

The remarks of Mr. Dunn are correct, that our capricious and ill-digested methods of legislation on the subject of water powers have not contributed to make enterprises of the kind more inviting, and this has raised the rates of interest at which money could be borrowed for this class of enterprise.

On the other hand, we are told that in Germany or some other European countries, there is no opposition between private enterprises and the government, such as has existed of late in this country. I should point out that this matter was disposed of by the very fact that in many instances, the German government has run these public service enterprises as a monopoly or has become a partner in them. For instance, there is no struggle between railroad companies in Germany and the German government for the reason that the German government owns and runs the railroads.

A short time ago, in studying the taxation system of Germany, I found that the earnings of the government railroads paid about 40 per cent of the total expenditures of the German government, and the general taxes of the country are reduced by this amount. In other cases of public service enterprises, like mines, etc., the government became an important partner in the enter- 
prise, and in this way, succeeded in controlling easily these enterprises from within, instead of trying to curb them by drastic legislation from without.

I do not say that we should copy these methods. I merely want to point out .where we are laboring under difficulties which might be removed if some way could be devised by which the government could enter into efficient cooperation with these enterprises. Some of the privately owned public enterprises in this country, I am sorry to say, have not always been carried out in the interest of the stockholders who had invested their money in these properties, and this too is a very important reason why capital has become shy and wants increased interest rates so as to make up for any contingencies of failure aside from fear of disturbing legislation. This undoubtedly has raised the fixed interest charges for any similar enterprises which might have to be launched.

In England, canals which once were privately owned, were subsequently bought up by railroads and they proceeded to take great care that the canals could not be used in competition with the privately owned railroad enterprises. In this country, we have become so "socialistic" as to have canals which belong to the state. I understand that in Germany, all the canals are owned by the government, and I know that they are kept in the most splendid condition of efficiency and the government can afford to maintain and improve them even if such action is in direct competition to the operation of its own railroads.

In general, there is a great difference in efficiency in any country when enterprises or the details of government are run by engineers and experts instead of by politicians.

Mr. Gano Dunn, a year ago, in this city of Washington, advanced the idea that an engineer should never mix in matters of government administration. I told him at that time, that I disagreed with him. Then after his interesting paper today, I disagree still more, because he has proved by his own example the versatility of our engineers.

We are encountering quite some difficulty in the problems of government of this nation. But we should not be too impatient. These matters are straightening themselves steadily-only a pessimist can deny this. We are confronted in this country with entirely new problems which have to be treated in new ways. These problems are considerably complicated by the immense and rapid growth of our Republic. The fact is that this country, as it grows larger and larger cannot keep on being run in the easy-going ways of a mining camp. We have come to a point where we have to change our methods, and in this we have to do some experimenting, just as we are doing in our chemical industries. If it were not for direct experimenting, our chemical industries could never have made progress. We are very lucky if, only once in awhile, some of those experiments are successful, and we do not count so much the ones which have been unsuc- 
cessful as long as we make headway. These problems cannot be solved by a general formula, inflexible and everlasting. Furthermore, whenever we discuss these problems, we are apt to be carried away by one single point of view or another and on this account, we frequently exaggerate one single feature by looking at it from one standpoint. This is the mistake of most of our politicians. When we talk about these matters, let us discuss them like engineers. Let us use quantitative argumentation and let us impress those of our friends in Congress or the Senate who are really willing to learn that we, at least, can look at the situation with a due sense of proportion by using quantitative arguments and not be overawed by merely qualitative considerations.

C. G. Atwater: The point I want to discuss is contained in the first sentence of the summary in Mr. Whitney's paper, namely, that the United States has no adequate source of fixed nitrogen. I think that point is open to some question. Further along the paper makes an exception of the gas and coke industry.

I presume that Mr. Whitney in writing the paper did not consider the dimensions of these industries nor the present conditions that prevail in them. As a matter of fact, so far from there being no source of fixed nitrogen, there is being produced every year in this country from the carbonization of coal to make coke about 750,000 tons of sulphate of ammonia, or equivalent to that. That figures up pretty nearly to our whole consumption of fixed nitrogen. It is not all being recovered, but it is a source known to be open for the recovery of that amount. There is at present being recovered of that amount about 220,000 tons of sulphate of ammonia per year.

That is a very fair proportion, but it is being largely increased. The development of the coking industry that has come with the present abnormal conditions, though largely from the natural growth of the iron and steel business, has brought about.very nearly the doubling of that industry, potentially, within the last few months; that is to say, contracts have been let for some 2600 coking ovens which will produce about 150,000 tons of sulphate of ammonia per year.

Now, as you will see, that is very far from the country being in a position of having no adequate source of fixed nitrogen.

I do not wish to make these suggestions from the point of view of checking or discouraging water power development, but when you come to figure these things out and deal with our friends the bankers and others, these points will have to be considered.

There is a tremendous increase under way in the by-product coke ovens, as I have said, and it will amount to more than I have stated, because I have only referred to ovens actually under contract. There are 2000 or 3000 more under consideration. The business of recovering the by-products wasted in 
coal is being rapidly developed to somewhere near the position which it should occupy. That is also being applied to the recovery of nitric acid. It will be possible to convert ammonia from coke ovens into nitric acid. There is no question also that the development of the coke ovens will contribute toluol and other substances essential in time of war.

Calvert Townley: I had an opportunity some fifteen months ago of visiting the nitrate pampas of Chile and of inspecting the methods used for getting out this valuable product. It may interest you if I say, that I was impressed with the possibility of very greatly cheapening that product to the ultimate consumer.

We must remember that for a long term of years the Chilean nitrates practically had a monopoly, that is to say, the output of Chilean nitrates so largely exceeded that of any other similar products that the competition of such products was unimportant. The nitrate earth of Chile was very rich and to work it was very profitable, no matter how inefficient might be the methods of extracting the nitrate, consequently the processes were crude in many respects, and the operators did not seek for the economomies which might have been practised if the pressure of competition had been severe. I am not a chemist but it was apparent even to me, as it would have been to any engineer, that there were possibilities of material improvement in the economy of the production of nitrate.

When I was there, owing to the European war the industry was prostrate. Only about 30 per cent of the plants in the country were in operation, and these were running on part time only. Some 30,000 laborers had been thrown out of employment, and I never saw a more discouraged and disheartened set of men than the operating officials who had to do with this industry. They did not know what was going to happen next. One thing which had happened was that they were studying to improve processes for the extraction of nitrate, and it is usually a safe prediction that when a body of men who have been interested in an industry for a long time have sufficient incentive to make improvements they will make them provided there is any considerable margin to work on.

Before the war the Chilean government received some 60 per cent of its annual revenues from export duty on this nitrate which amounted, in round figures, to about $\$ 11$ a ton. It is an arbitrary duty which of course can be changed, and because the industry was then almost prostrate the question of modifying this duty was being discussed. If artificial processes for getting fixed nitrogen should be established on a scale large enough to jeopardize the Chilean industry it is only a fair prediction that the Chilean government will reduce its export duty.

There is still a third direction from which a reduction in the cost of nitrate may come. The cost of transportation-bringing 
the Chilean nitrates from the pampas where are the mines and reduction mills to the American market, has been abnormally high. None of the reasons for this fact are fundamental; they are all more or less the result of monopoly or of limited facilities and the cost is consequently subject to future reduction should the transportation agencies be improved or competition become severe.

The very live possibility that our country may become involved in war and the pressing need of providing for such a contingency should not blind us to the fact that we have lived many years at peace with the world and are likely to so continue - therefore no plan for producing nitrogen will be economically sound which is not commercially practicable under peace conditions. While the quantity of nitrate in Chile has been seriously depleted it is still sufficient to supply the world for years to come and its early exhaustion can therefore by no means be counted upon. This means that any cost for power which we may now estimate to be low enough to permit the artificial fixation of nitrogen in competition with the natural salts, may have to be radically revised downward later on. That furnishes another reason why we must make every possible effort to cut down our power costs. On the other hand, of course all of the processes for the fixation of nitrogen as now known are relatively new and susceptible of much improvement. I understand that not more than 15 or 20 per cent of the electrical energy required by the arc process is actually used in the fixation of nitrogen. Perhaps some of my chemical friends will correct me if I am wrong.

L. H. Baekeland: It is 2.5 per cent.

Calvert Townley: Well, it is worse than I thought it was. That being the case, is it not fair to assume that with the brilliant minds which are at work on this problem a great improvement is likely to result? May we not hope that the processes will be so improved that the industry can prosper with very much greater power costs? A process with an efficiency of 2.5 per cent which could live and pay $\$ 7.50$ per h.p. per year could presumably do quite as well with a $\$ 22.50$ h.p. if the efficiency could be raised to 7.5 per cent. One way to have the processes improved is to get people into the business. We all know that there is no teacher like experience, that necessity is the mother of invention, and that if we can get not one, but a dozen, or fifteen, or twenty, or even a hundred corporations interested and competing with the hope of ultimate profit, such competition will bring out the best efforts of the brightest minds. The result will be that in this industry, as it has been in every other industry with which electricity has been connected, the efficiency will rise and costs will go down, making it possible to use power at a cost which now is entirely out of the question.

Those are to my mind important reasons why we should set ourselves earnestly to the task of getting this industry on a basis where it can go ahead. 
One thing very clearly shown in Mr. Dunn's paper, is how large a part the cost of capital plays in a hydroelectric enter prise. No engineer could fulfill his obligation to his client without considering the question of the security of any investment. Technical matters can occupy but an insignificant and minor position if there is a risk that the entire sum put into an enterprise, or any part of it, may be forfeited.

Capital conveys to many minds quite an erroneous notion. We are apt to think of it as something entirely separate and apart from ourselves. We think of a banker as a man who himself puts his own money into enterprises. Now that assumption is fundamentally wrong. Investors are not the bankers, they are the men in this room. They are all of us, and our friends. To be sure we do not individually build water or steam power plants for the very obvious reason that such enterprises require large sums of money and there must be some one who will undertake to find out whether or not an enterprise is right and sound and then get the necessary funds together for the undertaking. That is just what the banker does. He is a sort of Captain of Money. He scrutinizes an enterprise and agrees to or refuses to back it, not because he himself likes it, or because he does not like it but because he knows the sort of investments which his clients, you and I and our friends, are likely to put money into.

Some one said something here this afternoon rather critically about the lack of patriotism in capital. Now, capital is a commodity just like grain, or cattle or clothing. It can be obtained for a price and it goes where it can find the best market. Not one of us would stand silent, accused of lack of patriotism, but who is there here who would put his own savings into an unprofitable or an unsafe enterprise to help develop water powers in the west when he might invest it profitably somewhere else? To rail at the man with money because he will not let us have it at a lower rate than he can get elsewhere is just as unreasonable as to demand that our grocer sell us eggs at 30 cents per dozen when he can get 40 cents from every one else in the neighborhood.

As Mr. Dunn remarked, capital is an international fluid. It flows into channels of least resistance. The price of capital is affected by the same laws of supply and demand that govern the prices of every other commodity. If it is higher in this country than in some other country for any individual class of enterprises it is because that class of enterprises lacks some feature of fundamental value. In Mr. Dunn's comparison of the operating costs of typical steam and water plants the capital rental for steam is 19 per cent as against 77.4 per cent for water. If by creating public confidence in the stability of investment and otherwise making these projects financially attractive the rate could be reduced say from 7 per cent to 5 per cent the annual cost of a steam unit of power would come down 5.4 per cent and that of the water unit 22 per cent. 
One thing capital looks for is earning capacity, and another thing is stability. Nearly all enterprises can get capital at some price because there is an abundance of it; but when any project lacks certainty of ample earning power on the one hand or stability on the other, that fact will be reflected at once in the price of capital which will demand a higher return.

One thing America can do to reduce the rent of the capital which water powers need, is to remove all the unnecessary handicaps with which it is now loaded One of these is the lack of stability. Warned by the losses suffered in the past by many water power investors, cautious people now hesitate to incur similar risks; consequently, the source of capital supply is restricted to that extent and a higher rental prevails. If we can eliminate this disability capital rental will fall and the development of the water powers throughout the entire length and breadth of the land will be stimulated.

One speaker referred to the lower price of money abroad He mentioned the paternalism of Germany in handling their railroads and other enterprises, and by inference at least drew a comparison unfavorable to American bankers and their supposed unreasonable demands. As far as my information goes there is no more ruthless financier than this same German banker. He is certainly no more keen to lend his money to an unprofitable enterprise, or at a lower rate of interest, on account of patriotism, than the American or English or any other banker. During my tour in South America, I learned about some methods of the German bankers doing business in those countries. I found that they exacted rates of interest which even the most rapacious American banker would not think of asking at home. They did it for just one reason, local conditions justified the rate and they charged the market price for their money. They could get it and they are going to continue to get it. You can rest assured that when a foreign banker lends his money to hydroelectric enterprises in his country at lower rates of interest than the American banker does in the United States, it is because the foreign investment is more secure, because experience shows that the foreign government is going to protect that investment and the risk of loss is correspondingly reduced.

This afternoon Mr. Stott spoke about the low cost of power from steam and the increasing severity of the cost competition with which water powers had to contend. The more I study water powers the greater respect I have for steam and if water power is to prevail at all, we must do our utmost to bring its cost down to the lowest possible limit. If steam can get down lower, steam will be used and water power will not be developed. But every time the cost of water power comes down a little bit its use is broadened and a certain number of water powers which otherwise could not be commercially developed are worthy of consideration.

That is the task to which I think we should address ourselves. 
The erroneous and misleading impression that has so long prevailed in the minds of many people throughout the land who have not studied the problem carefully and which has been reflected in the views of our Congressmen, that water powers are very cheap and enormously profitable, is being gradually dissipated and the facts are becoming known. Congress needs only to learn the facts to act upon them in an effective and patriotic way with the same singleness of purpose with which we would apply ourselves to an enterprise for a client. But the feeling that water power development is abnormally profitable to the promoter is deep rooted and of long standing. It still prevails in many quarters. Some Congressmen believe that the interests of the public are in some way different from or antagonistic to those of the investor and that it is their duty to safeguard the people's cause by driving a bargain, so to speak, with capital and by trying to see how little they can do to induce investors to put their money into hydroelectric enterprises. It would be unfortunate if the government which is seeking to have its resources developed by private enterprise without contributing its credit or assuming any risks whatever should adopt a policy which will just not accomplish the desired result by reason of over zeal in attempting to drive a bargain with the investor who is in no way whatever obligated to supply funds for such enterprises.

George R. Smith: Since going to Congress I have given this subject consideration from the view point of the public as well as the investor. I take it, from what I have heard tonight, we do not all look at it from the view point of the capitalist, the man who invests his money. Now, I agree with you that there should be certainty of tenure, and there should be certainty of a reasonable return on the investment. I would say, in view of what little I have done in the way of helping along legislation that if the members of this Institute are ashamed of the sort of legislation which is before Congress for its consideration, as is indicated by statements made, that they have another guess coming, that there is nothing quite so bad as some of the remarks would indicate.

Ever since the veto of the James River Bill we have been trying to get legislation through Congress that would protect the public and at the same time protect the investor, and up to the present time we are just as far away from that as we were when we started. I think that the Shields Bill is no better, possibly no worse than previous bills that have been introduced on the subject.

I want to leave this thought with you. Mr. Dunn put his finger on the sore spot when he said that public utilities could be regulated by commissions, - but he failed to say what kind of commissions. Mr. Hugh L. Cooper appeared a little over a year ago before a committee of the House of Representatives, having under consideration the Adamson Water Power Bill, 
which is similar to the Shields Bill and stated that he was afraid of state legislators and state legislatures because he had seen so many awful things committed by them but had absolute confidence in members of Congress and, therefore, was in favor of Congress enacting a law that would authorize the Secretary of War to regulate the price and service of hydroelectric energy.

A few weeks ago in an article in the Outlook, when the Shields Bill was under consideration in the Senate, Mr. Cooper said that public utility commissions created by state legislatures will afford all the protection that is necessary for the public and favored state regulation of hydroelectric companies. I wish Mr. Cooper could understand when he appears before Congress at a time when we are seriously considering a piece of legislation which is so necessary as a thoroughgoing water power bill and makes a statement along one line and then in a short time afterwards makes a statement in the press diametrically opposed to the one he made before Congress, that he cannot be expected to be taken seriously. We understand that Mr. Cooper has shifted his position, but we are not quite so clear as to his motive.

There is a great deal of suspicion abroad concerning the motives of representatives of capital who are advocating. water power legislation; some of it is unfounded and some of it has a good foundation, a very good foundation. Now, going back to the matter that I wish to call your attention to, I will say that you have got to permit hydroelectric plants to combine in order to operate them economically. Every man who knows anything about the subject at all, knows that that is one of the fundamental principles of economy in dealing with hydroelectric plants. In some cases a number of these plants have combined, a very considerable number, and the moment plants located in different states are combined, state utility commissions cannot regulate them because the current becomes interstate.

In Minnesota we are about to receive power from Wisconsin where there is a large power plant supplying power to various projects. At the present time, Minneapolis, gets its current from Taylor Falls on the state boundary line between Minnesota and Wisconsin. How can a Minnesota Commission regulate current generated in Wisconsin and brought into our state? How can it tell what is a fair rate under that situation? How can it inspect the books of a plant located in Wisconsin, which sells power to the Consumers' Power Company located in Minnesota? The Minnesota Commission has jurisdiction as to how much the Consumers' Power Company, which is nothing more or less than a distributing company, pays for its current but it has no way of determining whether the price paid by the Consumer's Power Company to the Wisconsin company is a fair and reasonable charge, and, therefore, is unable to determine what would be a fair and just rate to patrons of the Consumers' Power Company.

Nothing short of a Federal Commission authorized to work in 
conjunction with state commissions will meet the situation which I have called attention to. Besides, under a Federal Commission, the work now being done by the Secretary of War, the Secretary of Interior and the Secretary of Agriculture, could be brought under a single head thus effecting a great saving to the government and assuring efficient regulation which would rebound to the benefit of the investor and the consumer.

The moment that the promoters, the investers, the engineers and the associations that are giving their time to this subject come to Congress with a fair proposition, fair to the public and fair to the investor, Congress will join hands with them in working out an efficient law. Congress is looking for light, it is looking for information. Members of Congress are also anxious to know why they are persecuted for daring to offer any objection to impending legislation that is offered by what is known as the water power monopoly.

Why, we know and you know better than I do, that the water power interests of this country are controlled by a very few men, the whole policy is dictated by a very few men. Mr. J. P. Morgan of New York City is one of the leadingfactors, and the General Electric Companies is the great big institution, with its subsidiaries, that controls the situation. I do not object to the monopoly because the development of hydroelectric power economically is a natural monopoly. The thing I object to is the refusal on the part of those owning the monopoly to admit that there is a monopoly and I object to their attempt to deceive the public as to the existence of such a monopoly, in order to defeat legislation having for its purpose the control and regulation of such a monopoly.

Mr. Cooper says in his article in The Outlook, that it is not a monopoly - he laughs at the idea, he scoffs at it - and yet we know it is a monopoly. Why do the water power interests try to deceive the public? What can be their purpose? Under such a condition of affairs is it surprising that members of Congress as well as the public, look with suspicion upon any suggestion coming from owners of this monopoly. But as long as the water power interest suppress the facts concerning the monopolistic tendencies of hydroelectric development, Congress of the United States cannot be blamed for its refusal to be rushed off its feet in the consideration of water power legislation.

D. B. Rushmore: I need not say that I came here absolutely as an individual. I came here in my capacity as a member of the Institute, and as a man who has spent his life on water power developments, and I will be frank with some of my experiences. I have never lost money to any extent in anything else except water power development. I have had a gentleman in New York tell me that he has had in one autumn sixtysix men who controlled water powers locally and also men from different countries come to him and ask him to help them to raise money for those water power enterprises. Now, there is 
one waterpower, not very far from New York, in which the man who controlled it for years was a friend of a friend of mine. This friend happened to call at our office, and he was turned over to me. He had the right to a waterpower and wanted to raise money to finance it, but could not do it. He had been working on it for years and no one would take it up. I had a friend of mine look it up and he said it was no good, that it would not pay, that it did not have a market. The proposition was finally taken to Chicago to people who were somewhat familiar with it. I know they had a difficult time raising the money, people did not want to go into it, they said it did not look good to them. The only place they could go to raise the money was to bankers familiar with the project. In my experience as an engineer I have always seen the pressure come from the other side. I presume there are in New York every year hundreds of men who control complete situations trying to raise the money for them. If you talk to a man who does not know anything about a waterpower, he will not listen to you. It seems to me there has been a great misconception about this matter.

Mr. Dunn has dealt with bankers and knows the difficulties of raising money and in my opinion his paper will add very much to the beneficial result of our meeting here. Mr. Townley's discussion can also be brought to the attention of those who are in any way interested in this very broad and important subject. The financing of water powers, as Mr. Townley said, very truly, is dependent on us. Would any of us invest our money in them. I know a couple of bond brokers who sell bonds in the Mohawk Valley. They go into Amsterdam and offer to sell farmers public utility and water power bonds, and what the farmers pay for the bonds depends on the conditions on which the water power can be installed and operated. The banker goes around and gathers up various opinions and finds out what the people will take the bonds for.

The time is here for a new era of publicity. We are all afraid of the things we do not know-what is behind the doors and what is not brought out is always largely open to suspicion. Take the public into your confidence, work with the public, put the cards right down on the table before the public and show them just what you have.

Oscar T. Crosby: The political problems confronting us in the development of our water powers are these:

First, to what extent shall the authority of the general government, as distinguished from that of the several states, determine the location, physical construction and physical operation of water power plants?

Second, what authority shall control the financial operations of water power companies, including in this phase the control of rates?

Third, assuming these two questions as settled in one way or another, what principle should underlie the control of rates, 
of financial organization, of return to capital and of possible acquisition by public authority of private property involved in water power developments? Let us take up these questions in the order I have indicated.

Navigable streams are now fully recognized as being under the jurisdiction of the general government. There is no contention as to the right of that government to determine for or against the placing in such streams of any obstructions whatever. There is very grave contention as to the conditions which may be constitutionally attached, or which in wise policy should be attacked, to a permission given by the general government in any particular case. Should the sole interest of navigation be consulted, with no consideration affecting investment except that the proposed works should not result in navigation costs greater than those which otherwise would fall upon the public?

Should consideration of flood effects, as distinguished from navigation effects, also enter? Should questions of injury and advantage to agricultural lands, through drainage or irrigation be considered by the United States authorities?

In raising these questions, we raise a series of constitutional issues which it would be long and hard to settle. Happily, they need not be settled. If Smith and Jones have overlapping and tangled rights in respect to a tract of land, and if Brown wishes to use the land, then, without waiting for the law's delay, the proposed use of the land may be effected by a joint grant, or by parallel grants from Smith and Jones to Brown. Let Smith be Uncle Sam, let Jones be the State of Ohio, and let Brown be a water power company, and we may proceed to determine the physical questions surrounding any situation in a navigable stream. We may even go further, and thus cover the difficulties as presented by the question as to what is a navigable stream, according to the Constitution. The existing legal definitions are such as would let almost any creek into the dignified company of streams, which must recognize in Uncle Sam their overlord.

In my early years, as a young officer of engineers, I examined a "navigable stream (?)" in a buggy. Rubber boots would have done as well, but for the length of the thing.

However extreme the case, we may rest assured that a handsome appropriation will settle most "state's rights" doubts as to the navigability question. But if no appropriation be involved a real issue, affecting validity of permits, remains to be solved. Co-operation of Smith and Jones is the true, practical solution of this, and of the other doubtful points concerning floods, drainage, etc.

But the United States appears in quite a different role than that of overlord and largess-giver, when we regard the public domain in our Western States. Are we dealing here with a sovereign, or with a mere landlord-proprietor, subject to the laws of the local sovereign-the state? In my judgment, that is the true view of the case. But it is a much contested point. 
As a citizen of the United States, concerned that all states, east and west, should be in the same relation to lands within their bounds, I should be loath to see any assumption of an imperium in imperio, by the general government, because it holds as trustee certain lands in certain Western States. As one easterner, I want to register my cession of title in these lands to the people of the states within which they live. But if this battle cannot be won, then it may at least be compromised by the same principle of co-operation in grants that has just been proposed in the case of navigable streams. But this compromise should go no further than is required for determining the physical elements, - the construction elements-of each case.

When we meet the matter of financial control in all its aspects, I am firmly convinced that the states alone should determine. Even if the courts should decide that the general government has a right to enter this field, yet would I contend that as a matter of policy it should not enter it.

There are good men in the Washington bureaucracy, but there are few efficient bureaucracies in all the world. Can men be established in this city to administer wisely through subordinates the distant affairs of a Californian hydroelectric company? Will it be a bearable burden if an operator in Oregon must communicate with Washington in all those intimate ways which have been made familiar to us by the Public Utility Commissions of our states? Is the burden not now heavy enough when recourse must be had in so many matters to boards sitting in state capitols? And shall we have in the same state one control for steam plant generation, and another for water generation of electricity? What confusion! What discouragement!

Let us hope that this madness of centralization of control in Washington will pass.

Let us now consider the principles of control, without respect to the question as to which of our dual sovereignties is to exercise that control.

Men invest money in public utilities, not in order to charge particular rates for service, but in an effort to earn a return on the capital invested. That is the objective. A just and reasonable rate is a rate that will cause money and energy to flow into the enterprise which performs a given service, whether that service be the sale of electric energy or the sale of bread or shoes.

Then since it is right that there should be control of monopolies and since public utilities are necessarily monopolies (in the long run and in respect to at least some part of their clientele), let this control express itself in contracts relating in plain terms and in specific figures the return on capital. Rates may then be left to those who conduct the operations, subject, of course, to the usual common law rule against discriminatory practises.

These contracts as to return on capital may vary very widely from case to case; they should generally be on a sliding scale basis, providing lower returns in proportion to assured success, 
but they should be specific and clear. Let us get away from the unreasonable "rule of reasonableness"-misrule of unreasonableness - which now leaves rates and returns almost wholly to the guess of commissioners. Most of them are good men, but good men are not always wise men, and even wise men should not be left to decide vast property interests without guiding principles which put all parties on notice as to their rights. Let us recognize that the inventor has destroyed the old common law rule of reasonableness, which was the rule of custom. Now the ferment of invention has, for nearly a hundred years, prevented custom from taking a "permanent set," and this ferment is destined to continue. Customary rates will not be established. Contract rates may be fixed to a limited extent, chiefly as maxima. But there is no difficulty in fixing returns to capital on a sliding scale in each contract for a public service.

And as to the final chapter, the possible taking over of a property by the public, we hear far too much about it. The old law of eminent domain seems to be forgotten. No "perpetual franchise" can hold against the right of the government to take anything it wants. No fixed term franchise can hold against that right. A grant of today may be taken tomorrow. But private property must be paid for if thus taken. Now, the terms of payment may be fixed far in advance, or may be left to a jury at any time. If we had contracts fixing possible (not guaranteed) returns on capital, those contracts interpreted in the light of actual results obtained by operation, and with known investment figures, would render relatively simple the now fearsome task of fixing a condemnation value.

I append a copy of the bill proposed by me some years ago to cover the matter of permits for water-power construction.

(See proposed bill referred to by Mr. Crosby in hearing before National Waterways Commission, Washington, November, 1911, pages 136 and 137.)

Gano Dunn: I want to do service to a friend and to say to the Honorable Congressman that he understood Mr. Baekeland exactly the reverse of what Mr. Baekeland meant about Congress. Mr. Baekeland's experience has been the same as that of all the rest of us when we came down here-we have been received very courteously and listened to with such attention that we have been made to feel that every member of Congress or the committee we have gone before has been extremely desirous of drawing out all the facts. This has caused us to revise some of our former false opinions to the contrary.

I would like to read to the Congressmen and others who may be interested, the official policy of the American Institute of Electrical Engineers in regard to these matters, especially in view of his suggestion that we develop and bring out a bill for specific suggestions as to how water-powers should be handled: "The governing body of the Institute has continued its special 
committee (on water power) in consequence of these successive invitations in view of the apparent appreciation on the part of the government that the services rendered by the American Institute of Electrical Engineers were scientific and professional and not commercial or political, that its committees dealt with fundamental engineering and economic principles of hydroelectric development that were outside the field of controversy, and that the function of the Institute being scientific and professional and not commercial or political, its status was one involving a high degree of disinterestedness in respect to matters on which its technical advice was sought."

Mr. Baekeland referred to an address which I had the honor of making before the Washington Society of Engineers some time ago, in which he mistakenly reported me as saying that engineers ought never to mix in politics and other things. What I said was that in the appointment of the Naval Advisory Board, I believed for the first time in history the engineer, as such, had been invited to sit on the bench of Government with the statesman and co-operate with and help him; but I also said that the engineer should never go so far as to think that he can take the place of the statesman. The function is different and requires a different kind of man. The engineer is not big enough to do both things, and if we appointed an engineer as Secretary of State, our diplomacy would be likely to suffer. Therefore, I feel that we should stay in our own province as technical experts, and advise about the things we know, we should go before the various committees of Congress and answer inquiries about these things, but it is to them we should leave the other questions of what bills should be drawn and what kind of political bodies should be created to do the regulating and administering of the affairs of the government generally. Something toward this aim is what we hoped to accomplish in organizing this meeting here for the discussion of water-powers. 